\title{
O Conceito de liberdade em Aristóteles, Hegel e Sartre: IMPLICAÇÕES SOBRE ÉTICA, POLÍTICA E ONTOLOGIA
}

\author{
[ The concept of freedom in Aristotle, Hegel and Sartre: Implications on ethics, \\ POLITICS AND ONTOLOGY ]
}

\author{
Márcio Luiz Silva * \\ Instituto Federal de Educação, Ciência e Tecnologiy do Sul de Minas Gerais, Brasil
}

Resumo: A liberdade constitui tema que sempre transpassou o ser no decorrer da história, tese que continua influenciando a construção da identidade do sujeito e a relação do homem com a sociedade pósmoderna. O discurso de liberdade e a necessidade de conceituá-la suscitaram o juízo de vários pensadores ao longo da historia ocidental. Nesse sentido, a delimitação do tema desse artigo visa à discussão do conceito de liberdade circunscrito nos pensamentos aristotélico, hegeliano e sartreano. O conceito polissêmico do termo liberdade exerce função ímpar enquanto instrumento de construção da identidade ética, política e ontológica do homem antigo, medieval, moderno e pós-moderno. Aristóteles, Hegel e Sartre foram grandes pensadores que analisaram a variável liberdade para além de sua acepção etimológica, tanto no plano teórico quanto pragmático, estendendo seu conceito para os domínios da ética, política e ontologia, campos que fortemente influenciam a definição de homem na sua historicidade. Embora haja uma grande amplitude temporal (antiguidade, modernidade e pós-modernidade) e espacial (perspectiva grega, alemã e francesa), determinadas obras de Aristóteles e de Hegel e a principal obra de Sartre possibilita uma analogia da evolução, não linear, do conceito de liberdade no espaço-tempo, permitindo definir quais dessas dimensões (política, ontologia e ética) alcançaram primazia e se destacaram nos grandes períodos históricos e considerando as grandes matrizes geográficas que influenciaram a filosofia ocidental. Assim, o objetivo do presente artigo consiste em analisar a problemática dos limites da concepção de liberdade, verificando algumas implicações nos campos da ética, política e ontologia, a partir a perspectiva aristotélica, hegeliana e sartreana. Em Aristóteles, o conceito de liberdade e o seu locus se encontram na interdependência entre a ética e a política, saberes indissociáveis no pensamento antigo. É no exercício da razão, pelo hábito, buscando a ética teleológica, que o
Abstract: Freedom is a theme that has always transcended being throughout history, a thesis that continues to influence the construction of the identity of the subject and the relation of man to postmodern society. The discourse of freedom and the need to conceptualize it have aroused the judgment of various thinkers throughout western history. In this sense, the delimitation of the theme of this article aims at the discussion of the concept of freedom circumscribed in the aristotelian, hegelian and sartrean thoughts. The polysemical concept of the term freedom has a unique function as an instrument for the construction of the ethical, political and ontological identity of ancient, medieval, modern and postmodern man. Aristotle, Hegel and Sartre were great thinkers who analyzed the variable freedom beyond its etymological meaning, both theoretically and pragmatically, extending its concept to the domains of ethics, politics and ontology, fields that strongly influence the definition of man in his historicity. Although there is a great temporal (antiquity, modernity and postmodernity) and spatial (Greek, German and French perspective) amplitude, certain works of Aristotle and Hegel and the main work of Sartre allows an analogy, nonlinear, of the evolution of the concept of freedom in space-time, allowing to define which of these dimensions (politics, ontology and ethics) reached primacy and stood out in the great historical periods and considering the great geographical matrices that influenced western philosophy. Thus, the aim of this article is to analyze the problematic of the limits of the conception of freedom, verifying some implications in the fields of ethics, politics and ontology, from the aristotelian, hegelian and sartrean perspective. In Aristotle, the concept of freedom and its locus lie in the interdependence between ethics and politics, inseparable knowledge in ancient thought. It is in the exercise of reason, through habit, seeking the teleological ethics, that man, a rational and political being by nature, finds the greatest virtue, the supreme good, that politics can

* Instituto Federal de Educação, Ciência e Tecnologiy do Sul de Minas Gerais-IFSULDEMINAS. m@ilto:marcgeo10@yahoo.com.br 
homem, um ser racional e político por natureza, encontra a maior virtude, o supremo bem, que a política pode proporciona: a felicidade, residência fixa da liberdade. Para Hegel, a liberdade está na política, no Estado, sociedade política consubstanciada como a síntese da dialética, visto que o Estado se configura como a melhor manifestação do Espírito absoluto, entidade essencialmente ontológica. A própria concepção de ética, no pensamento hegeliano, só encontra realização plena no Estado, materialização, por excelência, do Espírito (Geist) e consciência da razão do seu em si. Ao defender a máxima heideggeriana da precedência da existência sobre a essência, descartando uma essência em nome de uma condição humana, Sartre aponta para uma liberdade que independe da política ou de qualquer determinismo externo. Nesse consenso, a liberdade é uma questão de escolha do ser, questão ética, mas que depende da ontológica, ou seja, da tomada de consciência de si pelo homem e da assunção de sua condição humana.

Palavras-chave: necessidade; determinismo; polis; Geist; ser-para-si provide: the felicity, fixed residence of freedom. For Hegel, freedom is in politics, in the state, political society embodied as the synthesis of the dialectic, since the state is configured as the best manifestation of the Absolute Spirit, essentially ontological entity. The very conception of ethics, in hegelian thought, only finds full fulfillment in the State, materialization, par excellence, of the Spirit (Geist) and consciousness of the reason of its in itself. In defending the heideggerian maxim of the precedence of existence over essence, discarding an essence in the name of a human condition, Sartre points to a freedom that is independent of politics or any external determinism. In this consensus, freedom is a question of the choice of being, an ethical question, but depends on the ontological, that is, of the awareness of self by the human being and the assumption of his human condition.

Keywords: need; determinism; polis; Geist; being foritself

\section{INTRODUÇ̃̃o}

A liberdade é um tema que sempre permeou o ser ao longo da história e - continua influenciando a construção da identidade do sujeito e a relação do homem com a sociedade pós-moderna. Por ser uma temática transversal, a liberdade foi e continua sendo objeto de estudo de vários campos da filosofia.

O conceito de liberdade vem do termo grego eleuthería e designa, com efeito, o homem livre (MORA, 2001; GOBRI, 2007). Em latim, a etimologia da palavra liberdade está relacionada ao adjetivo liber (deriva de liberto), o qual se aplica ao "homem em que o espírito de procriação encontra-se naturalmente ativo" (MORA, 2001). Assim, a concepção de liberdade, em latim (libertas), pode ser definida como a condição daquele que é livre, a capacidade de agir por si mesmo, a autodeterminação, a independência ou a autonomia (JAPIASSU e MARCONDES, 2006). Segundo Mora (2001), nessa concepção latina, o homem livre é, então, o não submetido, e desse significado derivam os subsequentes como, por exemplo, o de ser capaz de fazer algo por si mesmo. Percebe-se, assim, que tanto para os gregos quanto para os latinos a liberdade se apresenta como um estado de ser. Para os gregos, o homem livre é diferente do escravo, enquanto que para os latinos ele assume uma responsabilidade perante a comunidade e também consigo mesmo (BUENO, 2007).

A noção de liberdade não só inclui a possibilidade de decidir, mas também a de autodeterminação, a ideia de responsabilidade para consigo mesmo e também para com a comunidade, uma vez que ser livre implica assunção de algumas obrigações (MORA, 2001).

Mora (2001) ressalta que a noção de liberdade sempre envolve três modos básicos de entendê-la: uma liberdade que pode chamar-se "natural", uma liberdade que pode chamar-se "social" (política) e uma liberdade que pode chamar-se "pessoal" (concebida como autonomia ou independência). Nesse sentido, a noção de liberdade permeia uma abordagem ontológica, "na qual o homem só é livre enquanto ser racional e disposto a agir como ser racional" (MORA, 2001); uma abordagem política, em que a liberdade ou autonomia, numa comunidade determinada, consiste na possibilidade de 
reger seus próprios destinos, sem interferência de outras comunidades; e uma abordagem ética, eventualmente baseada na ideia de que há no indivíduo uma realidade que não é, em termos estritos, "social", mas plenamente "pessoal" (MORA, 2001; JAPIASSÚ e MARCONDES, 2006).

Nessa mesma perspectiva, Japiassu e Marcondes (2006) lembram que o termo liberdade, também, pode ser analisado segundo três acepções ou sentidos diferentes: em um sentido político, a liberdade civil ou individual é o exercício, por um indivíduo, de sua cidadania dentro dos limites da lei e respeitando os direitos dos outros; em um sentido ético, trata-se do direito de escolha pelo indivíduo de seu modo de agir, independentemente de qualquer determinação externa; e liberdade de pensamento, que em seu sentido estrito, é inalienável. Esses sentidos podem oscilar entre as várias dimensões ou tipos de liberdade, apontadas por Mondin (2014) como liberdade física, moral, psicológica, política e social.

Abbagnano (2007) assevera, também, que o termo liberdade tem três significados fundamentais, correspondentes a três concepções que se sobrepuseram ao longo de sua história e que podem ser caracterizadas da seguinte maneira: (1) liberdade como autodeterminação ou autocausalidade, segundo a qual ela é ausência de condições e de limites; (2) liberdade como necessidade, que se baseia no mesmo conceito da precedente, a autodeterminação, mas atribuindo-a à totalidade a que o homem pertence (Mundo, Substância, Estado); (3) liberdade como possibilidade ou escolha, segundo a qual ela é limitada e condicionada, isto é, finita. Mora (2001) relembra que o conceito de liberdade foi entendido e usado de maneiras muito diversas e em contextos muito diferentes, desde os gregos até aos tempos atuais.

O discurso de liberdade e a necessidade de conceituá-la acompanharam vários pensadores ou correntes filosóficas ao longo da historia ocidental. Nessa perspectiva, a delimitação do tema do presente artigo visa à discussão do conceito de liberdade circunscrito nos pensamentos aristotélico, hegeliano e sartreano, e desenvolvido entre a antiguidade e a pós-modernidade.

A justificativa para a escolha do assunto reside na diversidade de conceitos que gira em torno da palavra liberdade e na sua função enquanto instrumento de construção da identidade ética, política e ontológica do homem antigo, medieval, moderno e pósmoderno. Aristóteles, Hegel e Sartre foram grandes pensadores que analisaram a variável liberdade para além de sua acepção etimológica, tanto no plano teórico quanto pragmático, estendendo seu conceito para os domínios da ética, política e ontologia, campos que fortemente influenciam a definição de homem na sua historicidade. $O$ pensamento grego, alemão e francês conseguiu situar a liberdade num locus bem definido dentro da relação polarizada pelo determinismo-libertarismo, por vezes salvando-a da influência desse binômio, representado pelo par necessidade-liberdade, na perspectiva científica, e pela relação fatalidade-liberdade no viés religioso. $\mathrm{Na}$ contemporaneidade, a liberdade é um dos principais discursos que emerge no seio do ativismo social e integra a ideia de ética e política que permeiam o homem e sua autonomia, sob diversos pontos de vistas e em diferentes lugares.

Mora (2001) e Japiassú e Marcondes (2006) apontam três sentidos ou dimensões da concepção de liberdade: a dimensão política, a ontológica e a ética. Dessas dimensões é possível elencar as perspectivas natural, social e pessoal para o conceito de liberdade. Esses sentidos podem, ainda, oscilar entre as várias acepções ou tipos de liberdade, apontadas por Mondin (2014) como liberdade física, moral, psicológica, política e liberdade social.

Embora haja uma grande amplitude temporal (antiguidade, modernidade e pósmodernidade) e espacial (perspectiva grega, alemã e francesa), determinadas obras de 
Aristóteles $(2001,2002)$ e de Hegel $(1980,1987,2001)$ e a principal obra de Sartre (2015) possibilita uma analogia da evolução do conceito de liberdade no espaço-tempo, permitindo definir quais dessas dimensões (política, ontologia e ética) alcançaram primazia e se destacaram nos grandes períodos históricos e considerando as grandes matrizes geográficas que influenciaram a filosofia ocidental. Acredita-se que é possível tecer uma provável historiografia da evolução, não linear, do conceito de liberdade, considerando sua abrangência no espaço e no tempo e suas acepções ética, metafísica e política, a partir do olhar mais próximo de algumas obras desses pensadores.

O surgimento da polis, na antiguidade, e a emergência do theós, na idade média, e do ánthropos, na modernidade, como subjectum, constituem elementos indispensáveis na análise evolutiva do conceito de liberdade. Contudo, a ideia de liberdade, durante o medievo, ficou diluída na própria ideia de divindade (theós) como fundamento, o que inviabilizar elencar um pensador medieval para discutir o tema. Justificado a não abordagem da temática no período medieval, ressalta-se que, ao lado de Sócrates e Platão, Aristóteles se destaca como um grande pensador que, direta ou indiretamente, abordou a temática liberdade em seus tratados sobre ética (ARISTÓTELES, 2001) e política (ARISTÓTELES, 2002). Somado a isso, devido seu alto nível de abstração para com a realidade e o homem, Hegel se distingue como um pensador moderno que situou a liberdade na perspectiva da dialética idealista, sobretudo em suas principais obras (HEGEL, 1980, 1997, 2001). Ainda que Merleau-Ponty (1999) se destaque como um dos grandes nomes da fenomenologia, discutindo a noção de liberdade objetiva como um fenômeno polarizado entre o determinismo e o possibilismo, a facticidade e a transcendência humana, foi com Sartre em sua obra "O ser e o nada" (SARTRE, 2015) que a temática da liberdade, no seu viés ético, ganhou mais voz e mais vez nas discussões emergentes na filosofia contemporânea.

Nesse sentido, o objetivo do presente artigo consiste em analisar a problemática dos limites da concepção de liberdade, verificando algumas implicações nos campos da ética, política e ontologia, a partir a perspectiva aristotélica, hegeliana e sartreana.

\section{ACEPÇÕES POLISSÊMICAS DO TERMO LIBERDADE NA HISTÓRIA DA FILOSOFIA OCIDENTAL}

Na narrativa mítica, sobretudo na tradição grega, o homem é um ser sem liberdade. Não é ele o gerador de seu futuro, na medida em que seu destino, sua sorte, sua porção (moira) já está traçada. Nesse fatalismo, uma das formas de determinismo, tudo o que acontece, tinha de acontecer e, se a fatalidade, ou o destino, rege todos os nossos passos, não temos liberdade, e nem temos, propriamente, presente ou futuro. No entanto, no Mito de Er, descrito na obra de Platão, aparece a possibilidade de escolha, permitindo ao homem gozar de liberdade dentro do seu destino fixo (moira):

Declaração da virgem Láquesis, filha da Necessidade. Almas efêmeras, vai começar outro período portador da morte para a raça humana. Não é um gênio que vos escolherá, mas vós que escolhereis o gênio. $\mathrm{O}$ primeiro a quem a sorte couber, seja o primeiro a escolher uma vida a que ficará ligado pela necessidade. A virtude não tem senhor; cada um a terá em maior ou menor grau, conforme a honrar ou a desonrar. A responsabilidade é de quem escolhe. O deus é isento de culpa (PLATÃO, 2002, p. 316).

Com o surgimento da polis, na antiguidade, o homem passa a gozar de certa liberdade, sempre vinculada com a coletividade. Segundo Constant (1985) o conceito 
de liberdade para os antigos consistia em exercer coletiva, mas diretamente, várias partes da soberania inteira, em deliberar na praça pública sobre a guerra e a paz, em construir com os estrangeiros tratados de aliança, em votar as leis, em pronunciar julgamentos, em examinar as contas, os atos, a gestão dos magistrados; em fazê-los comparecer diante de todo um povo, em acusá-los de delitos, em condená-los ou em absolvê-los; mas, ao mesmo tempo em que consistia nisso o que os antigos chamavam liberdade, eles admitiam, como compatível com ela, a submissão completa do indivíduo à autoridade do todo. Ressalta-se que esse gozo, proporcionado pela democracia grega, não era para todos, pois escravos, mulheres e crianças ficavam fora dos muros delimitados pela liberdade.

$\mathrm{Na}$ narrativa cristã, durante o medievo, o homem parece exercer a liberdade por meio do livre-arbítrio, mas, ao refletir um pouco mais, vemos que ele não é tão livre, já que o homem deve seguir as leis de Deus para ter um lugar no paraíso após a morte. Assim, na idade média, sobretudo durante a patrística, as discussões sobre a natureza e limites da liberdade giram em torno das obras de Agostinho (1995) e Boécio (1955). A liberdade assume uma tônica onto-teológica, na medida em que ser livre é gozar de livre-arbítrio tendo a opção de fazer o bem, mediante a graça, ou o mal, pela negação da graça. Em Agostinho (1995) e Boécio (1955), a liberdade vem de Deus, está em Deus e é garantida por Deus. Para a ética cristã, liberdade é precisamente o reconhecimento da lei objetiva do próprio amor, que, necessariamente, é cristão.

$\mathrm{Na}$ modernidade, vários pensadores se voltaram para a discussão sobre o problema da liberdade. Descartes, ao elaborar sua teoria racionalista, aborda a temática da liberdade, num viés predominantemente ontológico. Segundo o autor "... pelo próprio fato de ser eu uma substância, eu não teria, todavia, a ideia de uma substância infinita, eu que sou um ser finito, se ela não tivesse sido colocada em mim por alguma substância que fosse verdadeiramente infinita" (DESCARTES, 1996, p. 289-290). Assim, na teoria cartesiana, a própria ideia de liberdade está condicionada à existência de Deus, se dá em função da res infinita. Para Espinosa, a liberdade é "reconhecer-se como causa eficiente interna dos apetites e imagens, dos desejos e ideias, afastando a miragem ilusória das causas finais externas" (CHAUÍ, 1995, p. 72). Kant buscou uma conciliação entre o determinismo e libertarismo procurando compreender como era possível tanto a liberdade quanto a necessidade (BUENO, 2007). Kant afirma que, do lado determinista a liberdade é impossível, pois, segundo ele, no domínio dos fenômenos, que é o reino da natureza, há um completo determinismo. É totalmente impossível salvar dentro dele a liberdade. Porém, segundo Bueno (2007) Kant salva a liberdade pelo caminho da moralidade e da metafísica. Com Kant a liberdade fica justificada e a tensão entre necessidade e liberdade conciliada (BUENO, 2007). Numa abordagem pragmática, Bentham (1979) identifica o locus da liberdade e do livre arbítrio situado no equilíbrio entre o prazer e a dor, visto que o homem é escravo desses dois senhores. Em Bentham, é somente quando se anulam esses dois senhores, prazer e dor, que o homem ganha a liberdade, optando pelo bem. Segundo a ética utilitarista, polarizada pela moral e o direito, "a natureza colocou o gênero humano sob o domínio de dois senhores soberanos: a dor e o prazer" (BENTAHM, 1979, p. 3).

Na transição da idade moderna para a contemporânea, Marx aborda a questão da liberdade e do determinismo, na sua teoria do materialismo histórico e dialético. Segundo Borges et al. (2002), se Marx assume a compreensão de que o ser do homem não se define por sua consciência individual, mas por seu ser social, e que este é determinado pelas relações de produção, as quais, por sua vez, já estão predeterminadas, falta, então, liberdade ao homem. Em Marx, aparece um determinismo denominado de materialismo estrito, em que os condicionamentos 
materiais, como o econômico, decidem por nós. Nesse sentido, somos condicionados socialmente e livres racionalmente. No entanto, essa liberdade abstrata, total e absolutamente incondicionada, para pensar, sem poder agir de acordo com os pensamentos, isto é, sem poder agir livremente, não é liberdade humana.

No século XX, diversos filósofos da corrente fenomenológica abordaram a questão da liberdade na tentativa de superar a antinomia determinismo-liberdade. Para eles, a discussão sobre liberdade não se faz no plano teórico, segundo um conceito de liberdade abstrata, nem conforme uma concepção racionalista que privilegie apenas o trabalho da consciência, mas sim a partir da liberdade do sujeito encarnado, situado e como ser de relação (ARANHA e MARTINS, 2003). Na fenomenologia, os pólos determinismo-liberdade são representados como facticidade (imanência) e transcendência humana (MERLEAU-PONTY, 1999; ARANHA e MARTINS, 2003). Não estamos no mundo como as coisas estão. Nesse sentido, a transcendência é a ação pela qual o ser humano executa o movimento de ir além dessas determinações, não para negá-las, mas para lhes dar um sentido, assumido como a dimensão da liberdade (MERLEAU-PONTY, 1999; ARANHA e MARTINS, 2003).

Existem ainda autores que consideram que, para que haja o exercício da liberdade, é necessário criar uma condição política que a possibilite. Dentre esses autores, destaca-se Habermas $(1989,1997)$ e sua teoria ética. Posicionando a liberdade na dimensão da alteridade, Jaspers (1965) afirma que o homem só encontra a si mesmo por meio do outro e só se torna livre na medida em que o outro se liberta.

Alguns pensadores, no entanto, ao longo da história ocidental conseguiram situar bem o conceito de liberdade ou até mesmo salvá-lo da análise necessária e aporética entre determinismo-liberdade, definido no viés científico pelo binômio necessidadeliberdade e conceituado, na seara religiosa, pela relação fatalidade-liberdade. Dentre esses pensadores, destacam-se Aristóteles, Hegel e Sartre. Segundo Chauí (2000), além da concepção de tipo aristotélico-sartreano e da concepção de tipo estóico-hegeliano, existe ainda uma terceira concepção, a fenomenológica, que procura unir elementos das duas anteriores, introduzindo a noção de possibilidade objetiva à liberdade. Nessa concepção fenomenológica, a liberdade merleau-pontyana é a capacidade para darmos um sentido novo ao que parecia fatalidade, transformando a situação de fato numa realidade nova, criada por nossa ação (CHAUÍ, 2000). Não obstante, numa dimensão psicológica da liberdade e considerando o ponto de vista ontológico, ou seja, o que diz respeito à correlação entre a liberdade e a possível natureza profunda do ser humano, a liberdade pode ser qualidade essencial do homem, mas não constitui sua própria essência, como defenderam pensadores como Aristóteles, Agostinho e Kant, ou pode constituir a própria essência da natureza humana, tese defendida por Descartes e Sartre (MONDIN, 2014).

\section{A CONCEPÇÃo de LiBERdAde EM ARISTÓTEles: A ELEUTHERÍA COMO EUDAIMONÍA NO ENCONTRO DO ETHOS COM A PÓLIS}

Em Aristóteles, o próprio conceito de homem como um ser social ou animal político e racional (zoon politicon) já aponta para a noção de liberdade aristotélica: o homem só encontra a liberdade na polis, na cidade-Estado, ou seja, é no exercício político ou na pragmática política que está a ideia de liberdade no pensamento aristotélico. Segundo Reale e Antiseri (2003), Aristóteles considera o homem não só como um "animal racional", mas também como "animal político" (um ser vivo não político pode ser apenas um animal ou então um deus). Segundo Aristóteles: 
Fica evidente, portanto, que a cidade participa das coisas da natureza, que o homem é um animal político, por natureza, que deve viver em sociedade, e que aquele que, por instinto e não por inibição de qualquer circunstância, deixa de participar de uma cidade, é um ser vil ou superior ao homem (ARISTÓTELES, 2002, p. 14).

E é pela linguagem, através do símbolo, que o homem, dotado da palavra (logos) e não somente da voz (phone) como os outros animais, consegue comunicar o encontro com o outro, fazendo a inserção e integração do ethos na polis. Conforme Aristóteles:

Somente o homem, entre todos os animais, possui o dom da palavra; a voz indica dor e o prazer, e por essa razão é que ela foi outorgada aos outros animais. Eles chegam a sentir sensações de dor e de prazer, e fazerem-se entender entre si. A palavra, contudo, tem a finalidade de fazer entender o que é útil ou prejudicial, e, consequentemente, o que é justo e o injusto. O que, especificamente, diferencia o homem é que ele sabe distinguir o bem do mal, o justo do que não o é, e assim todos os sentimentos dessa ordem cuja comunicação forma exatamente a família do Estado (ARISTÓTELES, 2002, p. 14).

Nesse sentido, moral e política ou ética e política, em Aristóteles, estão associados, visto que ethos e polis constituem, no homem, duas dimensões de um mesmo fenômeno. "Aristóteles aplica ao termo política a um assunto único - a ciência da felicidade humana - subdivida em duas partes: a primeira é a ética e a segunda é a política propriamente dita" (LARA, 1989, p. 149). Lara (1989) ratifica que a filosofia ética de Aristóteles não adquire, contudo, a totalidade do seu significado se não completar a sua filosofia política, pois, para ele, ética e política se integram num todo único. Destarte, a ética encontra na política sua plena realização, transformando o indivíduo em cidadão. Para Aristóteles:

Ainda que este fim seja o mesmo para o indivíduo e para a cidade-Estado, o fim desta última parece ser algo maior e mais completo, seja a atingir, seja a preservar; e embora seja desejável atingir esse fim para um indivíduo só, é mais nobre e mais divino alcançá-lo para uma nação ou para as cidades-Estado (ARISTÓTELES, 2001, p. 18).

Consoante Reale e Antiseri (2003), o bem do individuo é da mesma natureza que o bem da Cidade, mas este "é mais belo e mais divino" porque se amplia da dimensão do privado para a dimensão do social, para a qual o homem grego era particularmente sensível, porquanto concebia o individuo em função da Cidade e não a Cidade em função do individuo. Aristóteles, aliás, dá a esse modo de pensar dos gregos uma expressão paradigmática, definindo o próprio homem como "animal político" (ou seja, não simplesmente como animal que vive em sociedade, mas como animal que vive em sociedade politicamente organizada). Nessa acepção, ao afirmar que "o homem é, por natureza, um animal político" (ARISTÓTELES, 2002, p. 146), o estagirita reitera a ideia de que a polis não é apenas uma invenção humana, mas sim uma criação da própria natureza. Nesse contexto, o Estado, a polis, é uma forma natural de associação, e sua natureza é, por si, uma finalidade: assegurar o viver bem (ARISTÓTELES, 2002). Segundo Arendt (2007, p. 48),

[...] se quiserem entender a coisa política no sentido da categoria meio-objetivo, ela era, tanto na acepção grega como na acepção de Aristóteles, antes de mais nada, um objetivo e não um meio. E o objetivo não era pura e simplesmente a liberdade tal como ela se realizava na polis, mas sim a libertação pré-política para a liberdade na polis. A coisa política entendida nesse sentido grego está, portanto, centrada em torno da liberdade, sendo liberdade entendida negativamente como o 
não-ser-dominado e não-dominar, e, positivamente, como um espaço que só pode ser produzido por muitos, onde cada qual se move entre iguais.

Nessa perspectiva, para Arendt (2007), a política aristotélica é o próprio exercício da liberdade. A liberdade é a prática política, reside na própria política (ARENDT, 2007).

Reale e Antiseri (2003) reforçam que o bem supremo realizável pelo homem (e, portanto, a felicidade) consiste em aperfeiçoar-se enquanto homem, ou seja, naquela atividade que diferencia o homem de todas as outras coisas. Assim, não pode consistir no simples viver como tal, porque até os seres vegetativos vivem; nem mesmo viver na vida sensitiva, que é comum também aos animais. Só resta, portanto, a atividade da razão. O homem que deseja viver bem deve viver, sempre, segundo a razão.

Assim, a concepção de liberdade (eleuthería) no pensamento aristotélico estava vinculada à polis, uma vez que a ética (ethos), ao buscar a felicidade (eudaimonía), através da virtude (areté), almejava, por um lado a bios theorétikós (vida contemplativa), e por outro, paradoxalmente, a política (ARISTÓTELES, 2001, 2002). Dessa forma, em Aristóteles a liberdade está associada à ação moral, que sempre tende ao bem, que é conhecido e querido pelo homem e se expressa na ação voluntária (BUENO, 2007). Cunha (2011) lembra que para Aristóteles, como também para Platão, a verdadeira felicidade ou o verdadeiro bem é sempre aquilo que é buscado por si mesmo e não com vistas em outra coisa, por isso ele é algo de absoluto e não relativo. Daí que as ações virtuosas sejam aprazíveis em si mesmas e a consequência disso é que o objetivo da vida política seja o melhor dos fins, pois essa ciência se esforça por fazer com que os cidadãos sejam bons, livres e capazes de nobres ações (CUNHA, 2011, p. 95).

Aristóteles defendia que toda ação moral almeja um fim. E que cada um destes fins, cada objetivo que traçamos, representa para nós um bem, e o maior bem para os seres humanos é a felicidade, pois todos os outros bens visam, direta ou indiretamente, à felicidade (REALE, 1994; ARISTÓTELES, 2001, 2002). Assim, a felicidade (eudaimonía), é o objetivo primordial da existência humana racional e, também, ética. Uma leitura possível e fundamental é a de que, em Aristóteles, a felicidade é o encontro com a vida política, é a forma do sumo bem, é a realização de todas as virtudes (areté), é a realização suprema da alma humana, manifestação da racionalidade.

Ora, parece que a felicidade, acima de qualquer outra coisa, é considerada como esse sumo bem. Ela é buscada sempre por si mesma e nunca no interesse de outra coisa, enquanto a honra, o prazer, a razão e todas as demais virtudes, ainda que as escolhamos por si mesmas (visto que as escolheríamos mesmo que nada delas resultasse), fazemos isso no interesse da felicidade, pensando que, por meio dela, seremos felizes. Mas a felicidade ninguém escolhe tendo em vista alguma outra virtude, nem, de uma forma geral, qualquer coisa além dela própria (ARISTÓTELES, 2001, p. 25).

A liberdade aristotélica surge, então, como a atividade racional que, pelo hábito, busca a virtude (o bem), visando dar uma finalidade para a existência. A realização da liberdade (dar uma finalidade para a existência) é a própria felicidade (sumo bem), proporcionada e garantida pela política.

Em Aristóteles, considerando a premissa de que a ética e a política constituem duas dimensões de um mesmo fenômeno e que ambas visam um mesmo fim, é possível afirmar que a liberdade conduz à alteridade, pois ninguém, na prática, exerce, sozinho, a liberdade. Destarte, o exercício da liberdade pressupõe o outro e, na intersubjetividade do eu com o outro, se encontra o nós, a coletividade, a sociedade, a política. E é na 
polis, locus da essência do animal racional e político (zoon politicon), que também reside a felicidade e com ela, a liberdade encontra sua razão de ser.

Segundo Constant (1985), o objetivo dos antigos era a partilha do poder social entre todos os cidadãos de uma mesma pátria. Era isso o que eles denominavam liberdade.

\section{O PROBLEMA DA LIBERDADE EM HEGEL: A IDEIA DE LIBERDADE NO DESENVOLVIMENTO diAlÉTiCo do EsPírito ABSOLUTO}

A compreensão do conceito de liberdade (Freiheit), em Hegel, só se realiza, necessariamente, através da apreensão do Espírito (Geist), que se manifesta em diferentes formas e diversos graus, em direção ao Absoluto (Absolut). A apreensão, captação, assimilação ou compreensão do que é cognoscível, diz respeito ao simples ato de conhecimento, através do qual o espírito capta imediata e diretamente os objetos ou os representa (JAPIASSÚ e MARCONDES, 2006). Quanto ao conceito de apreensão Hegel afirma que

Como verdadeiro princípio da filosofia deve-se considerar o momento, em que o absoluto já não é representação, e o sentimento livre não pensa somente o absoluto, mas apreende a idéia do absoluto: quer dizer, quando o pensamento reconhece o ser (que também pode ser o próprio pensamento) como a essência das coisas, como a totalidade absoluta e a essência imanente do todo (HEGEL, 1980, p. 380).

O espírito (Geist), em Hegel, é definido como "a comunidade de homens que toma consciência de si mesma na História" (LACOSTE 1986, p. 43). Assim, num sentido geral, Geist denota a mente humana e seus produtos, em contraste com a natureza e também com a ideia lógica (INWOOD, 1997). Quanto ao termo absoluto (Absolut), a descrição que mais interessou a Hegel foi a de Schelling, segundo o qual o absoluto é uma "identidade" neutra subjacente tanto no sujeito (ou espírito), quanto no objeto (ou natureza) (INWOOD, 1997). E nesse contexto, Inwood (1997) evoca que uma teoria do absoluto postula três tipos de entidade: o absoluto, o mundo fenomênico (rochas, árvores, animais, etc.) e o conhecimento humano do absoluto, do mundo fenomênico e das relações entre eles.

Nesse sentido, o "Espírito absoluto" engloba arte, religião e filosofia, suas três principais manifestações. Ao contrário do espírito subjetivo (o qual compreende toda a vida psicológica individual, desde a alma natural até o pensamento e a vontade) e do espírito objetivo (espírito comum de um grupo social, ethos da vida ético-política, consubstanciado em seus costumes, leis e instituições, ou seja, na moralidade, eticidade e direito), que são finitos, ele é infinito, uma vez que o espírito constitui aí um objetivo "para" o próprio espírito, mas também porque se reflete em algo distinto dele e, assim, limita ou restringe o espírito (INWOOD, 1997). Conforme Inwood (1997), Hegel vê o espírito subjetivo, objetivo e absoluto como, respectivamente, o conceito de espírito (Geist), sua realidade e a unidade de conceito e realidade. O Weltgeist (Espírito do mundo), espírito que se manifesta na História, é usualmente tratado sob o título de "espírito objetivo" e "direito", mas também é responsável pelo desenvolvimento da arte, religião e filosofia, e, assim, do espírito absoluto (INWOOD, 1997). O Volksgeist (Espírito de um povo) é semelhante ao espírito objetivo, mas inclui a contribuição de um povo para o espírito absoluto e, ao contrário do espírito objetivo, o Volksgeist ocorre no plural, ficando mais fácil vê-lo como espírito historicamente relativo e transitório (INWOOD, 1997). Por fim, segundo Inwood (1997), o Zeitgeist (Espírito da época, do 
tempo), que é uma fase do espírito do mundo, corresponde à mentalidade, vida social e produtos culturais de uma dada época, especialmente no seio de um determinado povo, que compartilham de um espírito comum.

Reale e Antiseri (2005) ratificam que o espírito é a ideia que retorna a si a partir de sua alteridade, é a mais alta manifestação do absoluto, o auto-realizar-se e o autoconhecer-se de Deus. Nesta ótica, ideia lógica e natureza são vistas como pólos dialéticos dos quais o espírito é a síntese viva. Assim, "o Espírito absoluto é a ideia que se autoconhece de modo absoluto, é Deus que se concilia com sua comunidade e consigo mesmo" (REALE e ANTISERI, 2005, p. 125). Da mesma forma, a Ideia absoluta, ou seja, a Razão autoconsciente, que se manifesta nas três determinações do espírito absoluto (arte, religião, filosofia), se realiza no Estado (Staat), denominado por Hegel de "realidade da Ideia" (ABBAGNANO, 2007).

Em Hegel, as ideias ou o ideal são, ontológica ou epistemologicamente, anteriores às coisas ou ao real. Diferentemente da ideia ou forma (Eidos) platônica, que tem existência plena, imutável, perfeita e universal, a ideia (Idee) hegeliana é a plena realização ou efetivação de um conceito. "Uma ideia não é um ideal que devemos realizar: ela é real no presente" (INWOOD, 1997, p. 171). Consoante Inwood (1997), a ideia reaparece então no domínio da natureza, como a ideia em sua alteridade, e no do espírito, como a ideia retornando a si a partir da alteridade. "Todo o real é uma Ideia" e a Ideia absoluta é a identidade do teórico e do prático, uma vez que "somente a Ideia absoluta é o ser" (MORA, 2001, p. 355).

A razão, no enfoque hegeliano, também não é um meio. A razão é o Espírito do mundo (Weltgeist), está presente em tudo. Porém, é somente no ser humano que ela pode vir a tornar-se consciente de si mesma (MORA, 2001; ABBAGNANO, 2007). A razão é a essência do mundo e a história (o próprio ser, visto que o ser não tem história, mas é história) é a realização da razão. E o ser (a história), para Hegel, traz em si a contradição, o real é contradição. Portanto, o desenvolvimento da razão corresponde ao caminho que a razão faz para ela mesma, visando entender o que ela é e tomando consciência de si mesma. Esse desenvolvimento da razão é contínuo, progressivo e pressupõe o eterno conflito, isto é, a dialética, que ocorre, na perspectiva hegeliana, em três fases: o primeiro momento (imediatidade) diz respeito ao conceito geral, o segundo momento (mediatidade) corresponde à materização desse conceito, a determinação do universal num particular, e o terceiro momento (suprassunção) coincide com a negação do particular, para suprassunção do particular no universal. Nessa sequência, a história da humanidade é a realização da razão e o Estado é a consciência da razão do seu em si, é a síntese da dialética. O Estado é a razão tomando para si a consciência do seu em si.

Como síntese de direito e moralidade e como possibilidade de ser da família e da sociedade, o Estado é a própria Ideia que se manifesta no mundo (REALE e ANTISERI, 2005). E nessa concepção, o Estado não existe para o cidadão, mas o cidadão é que existe para o Estado. Em suma, o cidadão só existe enquanto membro do Estado.

Para Reale e Antiseri (2005), se o Estado é a razão que faz o seu ingresso no mundo, a história, que nasce da dialética dos Estados, nada mais é que o desdobramento dessa mesma razão: "a historia é o desdobramento do Espírito no tempo, do mesmo modo que a natureza é o desdobramento da Ideia no espaço" (HEGEL, 2001, p. 123). Assim, a Ideia absoluta ou Espírito absoluto (a razão que se expressa na história da humanidade), é a Ideia que se autoconhece de maneira absoluta. E é nesse contexto, envolvendo o desenvolvimento dialético do Espírito absoluto e o papel do Estado como a própria Ideia que se manifesta no mundo, que surge e evolui o conceito de liberdade em Hegel. "O Estado é a racionalidade em si e por si, em que a liberdade chega a seu 
direito absoluto" (REALE e ANTISERI, 2005, p. 133). E a liberdade, que consiste no desenvolvimento do Espírito, só se encarna na figura do Estado. No entanto, para haver desenvolvimento é necessário movimento, e esse só é possível quando há contradição entre diferentes elementos, que na dialética hegeliana ocorre em três fases a partir de três esferas: na primeira esfera da ética, temos a esfera da relação matrimonial entre pais e filhos e da defesa do aumento do patrimônio da família; na segunda dessas esferas, ocorrem as relações sociais propriamente modernas; e no terceiro momento surge, então, o Estado, que se sucede de dois momentos anteriores, quando ocorre a suprassunção (HEGEL, 1980). Problematiza Hegel:

A Idéia universal se manifesta no Estado. A palavra 'manifestação' tem aqui um significado diferente do habitual. Em geral fazemos a distinção entre poder (potencialidade) e manifestação, como se a primeira fosse a essência e a última, não essencial, ou exterior. [...] O Estado é a realização da liberdade, do objetivo final absoluto, e existe por si mesmo. Todo o valor que tem o homem, toda a sua realidade espiritual, ele só a tem através do Estado. [...] Portanto, o Estado se torna o objeto preciso da história do mundo; é onde a liberdade obtém a sua objetividade e se mantém no gozo desta objetividade. A lei é a objetividade do Espírito, é a vontade em sua forma verdadeira. Só a vontade que obedece à lei é livre, pois obedece a si e, estando em si, sendo independente, ela é livre (HEGEL, 2001, p. 89-91).

Dessa forma, Hegel (2001) determina o Estado como a realização da Ideia, a matéria pela qual é realizado o objetivo final da Razão:

Este ser essencial é a união da vontade subjetiva com a vontade racional, é o conjunto moral, o Estado. É aquela forma de realidade em que o indivíduo tem e goza de sua liberdade, mas na condição de conhecer, acreditar e desejar o universo. [...] Afirmamos que a lei, a moral, o Estado - e só eles - são a satisfação e a realidade positiva da liberdade (HEGEL, 2001, p. 88).

Assim, em Hegel "o Estado é a liberdade e a moralidade” (DIMOULIS, 2014, p. 30). O Estado se manifesta não somente como Ideia moral objetiva, mas também como liberdade concreta:

O Estado é a realidade em ato da Ideia moral objetiva, o espírito como vontade substancial revelada, clara para si mesma, que se conhece e se pensa, e realiza o que sabe e porque sabe. No costume tem o Estado a sua existência imediata, na consciência de si, no saber e na atividade do indivíduo, tem a sua existência mediata, enquanto o indivíduo obtém a sua liberdade substancial ligando-se ao Estado como à sua essência, como ao fim e ao produto da sua atividade (HEGEL, 1997, p. 216).

Portanto, em Hegel, a liberdade, circunscrita no desenvolvimento dialético do Espírito absoluto, só alcança realização plena na esfera política, isto é, está no Estado e é garantida pelo Estado:

O Estado, como realidade em ato da vontade substancial, realidade que esta adquire na consciência particular de si universalizada, é o racional em si e para si: esta unidade substancial é um fim próprio absoluto, imóvel, nele a liberdade obtém o seu valor supremo, e assim este último fim possui um direito soberano perante os indivíduos que em serem membros do Estado têm o seu mais elevado dever (HEGEL, 1997, p. 217).

Hegel (2001) mostra que o Espírito é a liberdade de três maneiras:

O homem é parte Natureza e parte Espírito, mas sua essência é o Espírito. Quanto 
mais o homem se desenvolve espiritualmente, mais ele se torna consciente de si mesmo e quanto mais ele se torna consciente de si mesmo, mais ele se torna ele mesmo, ou seja, livre. $\mathrm{O}$ desenvolvimento do Espírito em direção à consciência de si na história do mundo é o desenvolvimento para uma liberdade sempre mais pura. A história do mundo é o avanço da liberdade, porque ela é o avanço da autoconsciência do Espírito. Depois, não apenas o homem se torna livre, mas o Espírito em si - no homem e através dele. O Espírito é essencialmente reflexivo e necessariamente faz de si uma certa ideia, de sua própria natureza. E assim ele chega a um conteúdo de sua reflexão, não descobrindo um conteúdo, mas colocando-se em seu próprio objetivo, em seu próprio conteúdo.” [...] Assim, “a liberdade, como o Espírito, é dinâmica, ela progride dialeticamente contra seus próprios obstáculos. Ela jamais é dada, deve-se lutar para obtê-la." [...] "Por outro lado, o Espírito ao superar assim seus próprios obstáculos elaborando e compreendendo a si mesmo na História é continuamente criativo, mas sua criatividade não é nada de ontologicamente novo, ela é predeterminada na potencialidade pura da Idéia pura. É a Idéia em si, a Razão, que se completa na História (HEGEL, 2001, p. 25-26).

Assim, a liberdade é, ao mesmo tempo, dada pelo Espírito absoluto, e desenvolvida pela história, que é racional. Hegel associa o conceito de liberdade não em contraste com a necessidade em si, mas com a necessidade externa envolvida em causalidade e reciprocidade (INWOOD, 1997). A liberdade é, portanto, a-histórica, embora seu desenvolvimento seja histórico.

Jaime e Amadeo (2006) lembram que, na filosofia do direito hegeliana, liberdade e propriedade constituem, num primeiro momento, faces de uma mesma moeda. Para os autores, o conceito de propriedade, em Hegel, deve ser pensado no âmbito de uma exterioridade que é o resultado dialético de uma subjetividade que consegue atualizar a sua própria liberdade dando-se um conteúdo próprio. Para Hegel:

Deve a pessoa dar-se um domínio exterior para a sua liberdade a fim de existir como ideia. Porque nesta primeira determinação, ainda completamente abstrata, a pessoa é a vontade infinita em si e para si, tal coisa distinta dela, que pode constituir o domínio da sua liberdade, determina-se como o que é imediatamente diferente e separável. O imediatamente distinto do espírito livre é para este e em si o exterior em geral, uma coisa, algo não livre, impessoal e ajurídico (HEGEL, 1997, p. 41-42).

De acordo com Jaime e Amadeo (2006), para Hegel, a subjetividade da pessoa só alcança objetividade e, portanto, liberdade, exteriorizando-se, e isso não pode ocorrer senão através da propriedade, a que se pode obter por apropriação corporal, pela elaboração, e por designação.

Todavia, embora a propriedade constitua o primeiro momento da dialética da liberdade, o momento de maior plenitude da ideia de liberdade, em Hegel, se dá no âmbito do Estado (JAIME e AMADEO, 2006). Hegel esclarece:

Mas para que o espírito objetivo, o conteúdo do direito deixem de ser concebidos através das correspondentes noções subjetivas, para que, por conseguinte, se deixe de conceber como um puro dever-ser isto de o homem em si e para si não estar destinado à escravatura, é preciso reconhecer-se que a idéia da liberdade só existe verdadeiramente na realidade do Estado (HEGEL, 1997, p. 57).

Em Hegel, ainda que a propriedade privada seja a primeira existência da liberdade, esta só pode se concretiza plenamente no âmbito do Estado. "Em tal sentido, é claro que, para Hegel, a propriedade privada nunca pode ser o fundamento do Estado, já que existe uma passagem da ideia de liberdade na propriedade através de uma 
superação da ideia de liberdade no Estado" (JAIME e AMADEO, 2006, p. 414).

Para Hegel, segundo Jaime e Amadeo (2006), no âmbito da família, a liberdade é um momento abstrato, pois os sujeitos ainda não foram atravessados pela individualidade. Na sociedade civil, a liberdade é realizada como liberdade negativa, enquanto a superação, ou seja, a recuperação do particular abstrato - em termos hegeliano, a vontade subjetiva e objetiva - só pode se realizar no âmbito do Estado (JAIME e AMADEO, 2006). Assim, "a finalidade do Estado é a realização da liberdade", entendendo o Estado não como um mero instrumento onde o universal fica resumido às vontades particulares, mas sim como a "realidade da ideia ética" (HEGEL, 1997, p. 257). É no Estado, universal concreto, onde serão conservadas e superadas as contradições da família e da sociedade civil (JAIME e AMADEO, 2006). Conforme Jaime e Amadeo (2006), pode-se afirmar que o axioma hegeliano é que no Estado a liberdade se faz objetiva e se realiza positivamente, sendo este o terreno da intersubjetividade, e não o do mero arbítrio individual.

Consoante Ambrósio e Santos (2010), o desenvolvimento do Espírito como consciente de sua liberdade só é possível dentro de uma esfera que una o Eu com o Nós, ou seja, de uma esfera em que a consciência-de-si possa reconhecer outra consciênciade-si como livre, como igual. Esse lugar é o Estado, que articula dentro de si os momentos dialéticos fundamentais do Espírito objetivo através do desenvolvimento do indivíduo como pessoa jurídica e como consciência moral às formas comunitárias da eticidade, ou seja, a família, a sociedade civil. Nessa mesma perspectiva, Salgado (1996) esclarece que a liberdade só é efetiva na identidade do eu (subjetividade) e do nós (ordem) pela mediação do mundo e é através do Estado (objetivação do nós) que o caminhar da liberdade se dá na história. Para Ambrósio e Santos (2010), o Estado hegeliano é o que realiza a liberdade plena, fim supremo de cada um, na superação dialética da sociedade civil e seu jogo de interesses pessoais. É na medida em que participa do Estado que o indivíduo é livre efetivamente, pois é só ali, segundo Hegel, que ele tem objetividade, verdade e moralidade.

Weber (2014) acentua que Hegel se refere ao Estado como a "efetividade da vontade substancial" na qual a "autoconsciência particular está elevada a sua universalidade". E nesta unidade substancial, sustenta o autor, a "liberdade atinge seu direito supremo" e o indivíduo tem o "dever supremo de ser membro do Estado". Portanto, a liberdade concreta significa a realização dos interesses particulares na universalidade, enquanto conciliados, superados e guardados, mas não eliminados (WEBER, 2014).

Em seu método dialético, Hegel identifica a liberdade como determinação racional do próprio ser: "liberdade é, em última instância, ser si mesmo. Esta noção da liberdade, embora com fundamento metafísico, não é, para Hegel, uma abstração: é a própria realidade enquanto realidade universal e concreta" (MORA, 2001, p. 415). A liberdade consiste, então, não em ser livre para fazer o que se quiser, mas em ser um ser humano plenamente desenvolvido (INWOOD, 1997). E este desenvolvimento da liberdade só se realizada na dialética, onde o Estado, superior manifestação do Espírito absoluto, faz a suprassunção, não a anulação, ante seus elementos precedentes: a família e a sociedade civil. Desse modo, todas as formas de liberdades expressas na liberdade hegeliana (liberdade de pensamento, de propriedade, de culto) só se concretizam e se tornam reais na figura do Estado, que é síntese, integração da realidade em eterno conflito entre tese e antítese.

Em Hegel, a liberdade não pode ser apenas exterior, nem apenas interior, pois ela se desenvolve na consciência e nas estruturas. A liberdade aumenta com a consciência que se tem dela, embora a simples "consciência da liberdade" ainda não seja a liberdade 
efetiva, isto é, real (VALLS, 2005). "Eu sou livre quando estou comigo. Essa existência autocontida do Espírito é a consciência própria, a consciência de si” (HEGEL, 2001, p. 64).

\section{5. A PROBlemÁtICA DA LIBERdAdE EM SARTRE: A LIBERDAdE COMO CONDIÇão E EXISTÊNCIA HUMANA}

Sartre eleva a liberdade (liberté) a um patamar nunca antes alcançado, ao comparar, metaforicamente, o termo liberdade com o termo condenação. Ao afirmar que estamos condenados a sermos livres, Sartre problematiza a liberdade tanto como possibilidade de condição quanto de existência humana. Sartre, em sua perspectiva existencialista, crê que o homem é livre, "porque somos aquilo que fazemos do que fizeram de nós". Haveria sempre a possibilidade de escolha a partir da condição em que nos encontramos, porque o homem nunca é um ser acabado, predeterminado. Ainda segundo o existencialista "não há diferença entre o ser do homem e seu 'ser livre"" (SARTRE, 2015, p. 68). Assim, para Sartre (2015, p. 695) "a liberdade é existência, e, nela, a existência precede a essência". Em $O$ ser e o nada, o existencialista faz uma ampla reflexão sobre a liberdade humana:

A liberdade humana precede a essência do homem e torna-a possível: a essência do ser humano acha-se em suspenso na liberdade. Logo, aquilo que chamamos liberdade não pode se diferençar do ser da "realidade humana". O homem não é primeiro para ser livre depois: não há diferença entre o ser do homem e seu "ser livre" (SARTRE, 2015, p. 68).

Com Sartre se inaugura uma nova visão de liberdade humana, pois para ele o homem é liberdade e está condenado à liberdade (BUENO, 2007). Em Sartre não existe mais uma liberdade interna e uma liberdade externa, mas uma única liberdade e com a qual o homem se constrói:

A liberdade não é nem interior nem exterior; em face desses seres, é "nada". A liberdade é, uma vez mais, a própria liberdade humana na medida em que faz livremente a si mesma. Existir humanamente é escolher, e o que se escolhe é a "escolha original" (e originária), para a qual não há razões e que, do ponto de vista racional, parece então "injustificada" e "absurda" (MORA, 2001, p. 419).

Em Sartre, o homem é homem pela sua condição de ser livre. O homem é fruto de sua liberdade porque quotidianamente escolhe as ações que irá praticar (SILVA, 2013). Dessa forma, a liberdade não é uma conquista humana, ela é uma condição da existência humana:

Com efeito, sou um existente que aprende sua liberdade através de seus atos; mas sou também um existente cuja existência individual e única temporaliza-se como liberdade. Como tal, sou necessariamente consciência (de) liberdade, posto que nada existe na consciência a não ser como consciência não tética de existir. Assim, minha liberdade está perpetuamente em questão em meu ser; não se trata de uma qualidade sobreposta ou uma propriedade de minha natureza; é bem precisamente a textura de meu ser; e, como meu ser está em questão em meu ser, devo necessariamente possuir certa compreensão da liberdade (SARTRE, 2015, p. 542-543).

Assevera Silva (2013) que Sartre conceitua a liberdade como uma condição intransponível do homem, da qual, ele não pode, definitivamente, esquivar-se, isto é, o ser humano está condenado a ser livre e é a partir desta condenação à liberdade que o 
homem se forma. "O homem usa a sua liberdade para escolher o que projeta ser" (SILVA, 2013, p. 95).

Segundo Silva (2010), Sartre define o para-si como liberdade. O ser para-si (consciência) é definido aqui como um tipo de ser que difere radicalmente do ser em-si. Enquanto este é definido como um ser que é o que é, isto é, um ser maciço, sem fissuras, pleno de si de canto a canto, o para-si se nos apresenta como um ser que traz em seu bojo a indeterminação e a falta (SILVA, 2010). Dito de outra forma, o para-si não pode coincidir consigo mesmo, isto é, ele engendra sua existência numa perpétua relação com o mundo circundante onde o nada (não-ser) permeia toda essa relação. Assim, ao invés de ser o que é, aos moldes do em-si, o para-si deve ser, isto é, deve criar constantemente seu modo de ser. Diferente do caráter estático do mundo factual (ser-em-si), o movimento do ser-para-si é relacionado com a liberdade, é livre (RODRIGUES e GONDIM, 2012). Schneider (2006) preceitua que o ser que é em-si, que coincide consigo mesmo, não pode ser livre, já que está condenado ao determinismo de ser o que é. "O homem, outrossim, ainda que pretenda, não consegue coincidir consigo próprio, posto que 'é o que não é e não é o que é', o que quer dizer que ele é obrigado a fazer-se, em vez de, simplesmente, ser” (SCHNEIDER, 2006, p. 296). Para Sartre:

O Em-si é pleno de si mesmo, e não poderíamos imaginar plenitude mais total, adequação mais perfeita do conteúdo ao contingente: não há o menor vazio no ser, a menor fissura pela qual pudesse desligar o nada. A característica da consciência, ao contrário, é ser uma descompressão do ser. Impossível, de fato, defini-la como consciência consigo mesma. Desta mesa, posso dizer que é pura e simplesmente esta mesa. Mas, de minha crença, não posso me limitar a dizer que é crença: minha crença é consciência (de) crença. [...] Assim, pelo simples fato de minha crença ser captada como crença, já não é apenas crença, ou seja, já não é mais crença: é crença perturbada. Assim, o juízo ontológico "a crença é consciência (de) crença" não pode em nenhuma hipótese ser tomado como juízo de identidade: o sujeito e o atributo são radicalmente diferentes, embora na unidade indissolúvel de um mesmo ser. [...] O Para-si é o ser que se determina a existir na medida em que não pode coincidir consigo mesmo. [...] Este ato perpétuo pelo qual o Em-si se degenera em presença a si é o que denominamos ato ontológico. O nada é o ato pelo qual o ser coloca em questão seu ser, ou seja, precisamente a consciência ou Para-si. [...] O Para-si é, mesmo que apenas a título de ser que não é o que é e é o que não é (SARTRE, 2015, p. 122-128).

Uma vez definido como liberdade, o para-si deve escolher seu modo de ser. Para realizar tal empresa, Sartre argumenta que o homem deve assumir inteiramente a autoria de seu projeto existencial. Dito de outra forma, o para-si deve ser o único responsável pelas suas escolhas no mundo. Nesse sentido, Sartre defende que o homem é inteiramente livre, ou seja, ele não é um ser determinado a priori (SILVA, 2010). Consoante Sartre (2015), o homem, na sua dualidade em-si e para-si, é uma liberdade que escolhe, mas escolhe ser livre, pois já está condenado a ser livre. E a liberdade, que não determina o ser a priori, é uma imposição, uma condição. Para Sartre:

Parece haver aqui uma espécie de precedência ontológica do Em-si em relação ao Para-si. [...] O Para-si é livre. Mas isso não significa que seja seu próprio fundamento. Se ser livre significasse ser seu próprio fundamento, seria necessário que a liberdade decidisse sobre a existência de seu ser. E tal necessidade pode ser entendida de duas formas. Em primeiro lugar, seria preciso que a liberdade decidisse acerca de seu ser-livre, ou seja, que fosse não somente escolha de um fim, mas escolha de si mesmo como liberdade. Portanto, haveria a pressuposição 
de que a possibilidade de ser-livre e a possibilidade de não ser livre existisse igualmente antes da livre escolha e uma delas, ou seja, antes da livre escolha da liberdade. Mas, uma vez que seria necessário então uma liberdade prévia que escolhesse ser livre, ou seja, no fundo, que escolhesse ser o que já é, seríamos remetidos ao infinito, pois ela teria necessidade de outra liberdade anterior que a escolhesse, e assim por diante. De fato, somos uma liberdade que escolhe, mas não escolhemos ser livres: estamos condenados à liberdade (SARTRE, 2015, p. 596-597).

Certifica Silva (2013) que a única coisa que o homem não pode optar é não ser livre, porque provocaria a renúncia de si mesmo. Sua liberdade é o alicerce de toda a moral, mas nada explica que este ou aquele valor seja melhor. Se a liberdade do homem é o alicerce absoluto, então, a moral não existe senão no próprio homem, manifesta, exclusivamente, em seu agir concreto.

Ao colocar o princípio da primazia da existência sobre a essência e ao afirmar que somos seres condenados à liberdade, Sartre (2015) discute a natureza e os limites da liberdade num viés nunca antes abordado: o da ótica existencialista. A liberdade, em Sartre, é colocada então, num patamar nunca antes posto. Em Sartre, nós sempre nos tornaremos aquilo que decidimos ser, e nunca importará o que fizeram de nós, mas o importante será sempre o que decidimos fazer com aquilo que fizeram de nós. A escolha é sempre uma opção humana, no viés existencialista. E essa escolha (liberdade) vem sempre acompanhada pelo crivo da responsabilidade. Ser livre, na perspectiva sartreana, implica fazer escolhas; e fazer escolhas implica assumir, sempre, a responsabilidade pelas escolhas feitas.

Assim, a liberdade pode ser vista como uma entidade metafísica, pois só existe plenamente na realidade do nosso intelecto, quando somos capazes de transcender as ideologias que nos condenam e nos condicionam, enquanto seres pensantes. Schneider (2006) salienta que a liberdade em Sartre é um conceito ontológico, pois ela é definidora do ser da realidade humana. O homem enquanto liberdade é o sujeito de sua própria história (engendrando aquilo que designou como compromisso ontológico), ao mesmo tempo em que é também sujeito da história da humanidade (desdobrando-se no compromisso político), constituindo-se, dessa forma, no produtor da realidade social, da qual, dialeticamente, é também produto (SCHNEIDER, 2006). No entanto, Sartre (2015) apresenta essa liberdade como algo independente do interior e do exterior do ser, como uma condição que não se permite ser negada pelo homem. Rodrigues e Gondim (2012) atestam que, para Sartre não há um "por trás", uma essência das coisas. Para ele, "as aparições que manifestam o existente não são interiores nem exteriores: equivalemse entre si, remetem todas as outras aparições e nenhuma é privilegiada" (SARTRE, 2015, p. 15). Assim, o homem está condenado a ser livre e consequentemente a ser responsável pelos seus atos.

Schneider (2006) reforça que a liberdade sartreana não é somente dizer que se quer algo, mas fazê-lo acontecer. O homem é aquele que faz e nesse fazer se faz. "Portanto, a liberdade não diz respeito ao plano moral, da escolha entre o 'bem e o mal', mas sim ao plano ontológico, da escolha de ser. A liberdade é constitutiva do ser do homem" (SCHNEIDER, 2006, p. 298). Conforme Pires (2005), desta forma, admitir que somos livres implica no nada que gera essa liberdade. Somos livres devido à total indeterminação que o nada gera. "A liberdade não é algo que deva ser conquistado. Existir é ser livre. A liberdade se dá indissociadamente com a existência” (PIRES, 2015, p. 7). Assim, em Sartre (2015), a liberdade, que se define na dimensão ontológica e se relaciona com o ser do para-si, significa, necessariamente, autonomia de escolha. Sartre assegura: 
Mostramos que a liberdade se identifica com o ser do para-si: a realidade humana é livre na exata medida em que tem-de-ser seu próprio nada. [...] E o ato fundamental da liberdade... é este ato que confere seu sentido à ação em particular que levo em consideração em dado momento: este ato constantemente renovado não se distingue de meu ser, é escolha de mim mesmo no mundo e, ao mesmo tempo, descoberta do mundo (SARTRE, 2015, p. 559 e 569).

Assumir essa liberdade, no existencialismo sartreano, implica assumir a condição da consciência de si mesmo, assumir o seu papel político e social, fazendo uso de uma ética a serviço do ser. Significa, para o homem, assumir a responsabilidade ética e política pelos seus atos, enquanto ser.

Uma das deficiências referentes à crise axiológica da atualidade reside no fato de sempre buscarmos um ser, evocar algo que assuma as consequências dos nossos atos. Nessa perspectiva, a liberdade em Sartre, no contexto contemporâneo, está ligada e permeada por todos os grandes problemas que afligem o homem na atualidade.

Em Sartre, o próprio fundamento da existência e da condição humana reside na liberdade, configurada, paradoxalmente como condenação e responsabilidade que conduz o ser a seu status de ser livre. E a liberdade é condição e existência, é o ser-em$s i$, mas também é, em dualidade, possibilidade, escolha e responsabilidade, é o serpara-si. No existencialismo sartreano, não há uma natureza humana, pois a essência é precedida pela existência e a existência é liberdade, escolha autônoma para definir o que queremos ser.

\section{ConClusão}

Ao longo da história da filosofia é possível perceber que a análise da temática da liberdade oscilou, sobretudo, entre os campos da ética, da política e da ontologia.

Em Aristóteles, o conceito de liberdade e o seu locus se encontram na interdependência entre a ética e a política, saberes indissociáveis no pensamento antigo. É no exercício da razão, pelo hábito, buscando a teleologia da ética, que o homem, um ser racional e político por natureza, encontra a maior virtude, o supremo bem, que a política pode proporcionar: a felicidade, residência fixa da liberdade. É no encontro da ética (ethos) com a política (polis) que o homem, animal social por excelência, único dotado de logos, encontra e exerce sua liberdade. Assim, a liberdade aristotélica conduz o ser à alteridade, pois a eleuthería não é pessoal, ou seja, ninguém é livre sozinho, e o seu exercício pressupõe o outro que, intersubjetivamente se desloca para o nós, para a política, locus do zoon politicon, da eudaimonía, razão de ser da liberdade.

Para Hegel, a liberdade se realiza num plano de natureza predominantemente política e de cunho ontológico. Ela é definida e garantida pelo Estado, sociedade política consubstanciada como a síntese da dialética hegeliana, visto que este se configura como a melhor manifestação do Espírito absoluto, entidade essencialmente metafísica. A própria concepção de ética, no pensamento hegeliano, só encontra realização plena no Estado, que é a materialização, por excelência, da esfera pública, se configurando como a própria Ideia que se manifesta no mundo. Assim, a liberdade só surge e se exercita, se garante, se concretiza e encontra sua razão de ser e sua plenitude se circunscrita nessa entidade metafísica: o Estado, a síntese dialética e a principal manifestação do Geist, a racionalidade em si e por si. Em Hegel, simultaneamente, a liberdade é dada pelo Espírito e desenvolvida pela História, que é racional. Ela é, pois, de natureza a-histórica, não obstante seu desenvolvimento seja histórico. Assim, na perspectiva hegeliana, a ideia da liberdade só existe verdadeiramente na realidade do 
Estado: na família, a liberdade só existe enquanto abstração, ao passo que na sociedade civil, ela é negativa. Somente no Estado a liberdade deixa de ser abstrata e negativa, tornando-se, dialeticamente, através da suprassunção estatal, positiva, efetiva e objetiva, enfim, plena de si mesma. Consequentemente, a efetividade da liberdade só existe na identidade do eu e do nós pela mediação do mundo, sendo o Estado responsável pelo caminhar da liberdade na história. É na medida em que participa do Estado que o indivíduo é livre efetivamente, pois é no Estado que a liberdade encontra objetividade, verdade e moralidade. É no Estado que a realização dos interesses particulares na universalidade são conciliados, superados e guardados, mas não eliminados, é onde a liberdade se concretiza. Dessa forma, embora com fundamento metafísico, a concepção de liberdade, em Hegel, não é uma abstração. Ela é a própria realidade enquanto realidade universal e concreta. Ela é, em última instância, ser si mesmo. Não é exterior ou interior ao ser, ela se desenvolve na consciência e nas estruturas.

Assim como em Aristóteles quanto em Hegel, a liberdade tem na política seu locus: na concepção aristotélica o exercício da liberdade ocorre somente na polis, enquanto que na perspectiva hegeliana a garantia, a plenitude, o exercício e a própria liberdade está no Estado, é o Estado. No entanto, enquanto a liberdade aristotélica somente se efetiva na integração da ética com a política, sua razão de ser, na concepção hegeliana, a liberdade plena só existe a partir da suprassunção efetivada pelo Estado, não através do encontro da ética com a política, mas através da ontologia, configurada pelo movimento dialético do Espírito absoluto.

Em Sartre, não existe diferença entre o ser do homem e seu ser livre, pois o homem não é primeiro para depois ser livre. Não existe mais uma liberdade interna ou externa, mas uma única liberdade e com a qual o homem se constrói. A liberdade não é moral, definida pela escolha entre o bem e o mal, mas ontológica, envolvendo a escolha do ser pelo ser, com vistas à constituição do ser do homem. Ela não é uma conquista, mas condição, é existência que precede a essência. Dessa forma, ao defender a máxima heideggeriana da precedência da existência sobre a essência, descartando uma essência em nome de uma condição humana, Sartre aponta para uma liberdade que independe da política ou de qualquer determinismo externo. Nesse consenso, a liberdade é uma questão de escolha do ser, questão puramente ética, mas que depende da questão ontofenomenológica, ou seja, da tomada de consciência de si pelo homem e da assunção de sua condição humana. A liberdade, em Sartre, é o ser para-si que, diferente do em-si que se define como um ser que é o que é, o para-si não coincide consigo mesmo (senão estaria condenado ao determinismo de ser o que é), isto é, ele engendra sua existência numa perpétua relação com o mundo circundante onde o não-ser (o nada) permeia toda essa relação. Somos livres justamente devido à total indeterminação que o nada gera. Assim, a liberdade se identifica com o ser do para-si, pois a realidade humana é livre na exata medida em que tem-de-ser seu próprio nada. Assim, enquanto o ser-em-si é ato, o ser-para-si é potência, é liberdade em sua plenitude perante o nada, é uma liberdade que escolhe, mas escolhe ser livre, pois já está condenada a esta condição. Nessa perspectiva, não há, no existencialismo sartreano, uma natureza humana, pois a essência é precedida pela existência e a existência é liberdade, escolha autônoma para definir o que queremos ser. Enquanto liberdade, o homem é sujeito de sua própria história, ao mesmo tempo em que é protagonista da história da humanidade, é produtor e, dialeticamente, produto da realidade histórica e social. Por isso, a liberdade, à luz sartreana, é uma questão ética, mas também uma problemática onto-fenomenológica, praemissa venia, no mais alto pragmatismo da ontologia.

Nessa sequência, tanto no viés hegeliano quanto sartreano, a liberdade deve ser absoluta, deve estar imersa na totalidade: para Hegel, a liberdade não é exterior ou 
interior ao ser, mas ela se desenvolve na consciência e nas estruturas; ao passo que para Sartre não há uma liberdade interna e uma liberdade externa, mas uma liberdade única, que se configura no nada e que se confunde com o ser, com a qual o homem se constrói continuamente.

Se em Aristóteles a liberdade é o exercício político, a libertação pré-política para a liberdade na polis, e em Hegel ela consiste não em ser livre para fazer o que se quiser, mas em ser um ser humano plenamente desenvolvido, em Sartre, a liberdade não é somente dizer que se quer algo, mas fazê-lo acontecer. O homem é aquele que faz e nesse fazer se faz. Se em Aristóteles, o homem livre é aquele que partilha do poder social entre os iguais, e em Hegel quanto mais o homem se desenvolve espiritualmente, mais ele se torna consciente de si mesmo e quanto mais ele se torna consciente de si mesmo, mais ele se torna ele mesmo, ou seja, livre, em Sartre, a liberdade é escolha autônoma, do ser em-si para o ser para-si. Ao passo que em Hegel, eu sou livre quando estou comigo, quando o ser adquire a consciência de si participando do Estado, em Sartre, a liberdade, o para-si, não pode coincidir consigo mesmo, mas deve buscar sua existência num contínuo nexo com o mundo onde o nada transpassa toda a relação.

\section{REFERÊNCIAS}

ABBagnanO, N. Dicionário de filosofia. 5. ed. São Paulo: Martins Fontes, 2007.

AGOSTINHO, S. O livre-arbitrio. 3. ed. Trad. Nair de Assis Oliveira. São Paulo: Paulus, 1995.

AMBRÓSIO, J. M. C.; SANTOS, M. C. O. Estado e liberdade em Hegel. In: SALGADO, J. C.; HORTA, J. L. (Coord.). Hegel, liberdade e Estado. 1. ed. Belo Horizonte: Fórum, 2010, p. 229-245.

ARANHA, M. L. A.; MARTINS, M. L. P. Filosofando: Introdução à filosofia. 3. ed. São Paulo: Moderna, 2003.

ARENDT, H. O que é política? Trad. Reinaldo Guarany. 7. ed. Rio de Janeiro: Bertrand Brasil, 2007.

ARISTÓTELES. Ética a Nicômaco. Trad. Pietro Nasseti. São Paulo: Martin Claret, 2001.

ARISTÓTELES. Política. Trad. Torrieri Guimarães. São Paulo: Martin Claret, 2002.

BENTHAM, J. Uma introdução aos princípios da moral e da legislação. 2. ed. São Paulo: Abril Cultural, 1979.

BOÉCIO. La consolación de la Filosofia. Traducción del latín por Pablo Masa. Buenos Aires: Aguilar, 1955.

BORGES, M. L.; DALL'AGNOL, D.; DUTRA, D. V. Ética. Rio de Janeiro: DP\&A, 2002.

BUENO, I. J. Liberdade e ética em Jean-Paul Sartre. 2007. 117 f. Dissertação (Mestrado em Filosofia) - Faculdade de Filosofia e Ciências Humanas, Pontifícia Universidade Católica do Rio Grande do Sul, Porto Alegre, 2007.

CHAUÍ, M. Convite à filosofia. São Paulo: Ática, 2000.

CHAUÍ, M. Espinosa, uma filosofia da liberdade. São Paulo: Moderna, 1995. (Coleção Logos).

CONSTANT, B. Da liberdade dos antigos comparada à dos modernos. Revista Filosofia Política, n. 2, 1985.

CUNHA, M. H. L. O conceito de liberdade e suas interfaces. Ensaios Filosóficos, v. 3, p. 93-104, 2011.

DESCARTES, R. Descartes. São Paulo: Nova Cultural, 1996. (Coleção os Pensadores).

DIMOULIS, D. Manual de introdução ao estudo do direito. 6. ed. São Paulo: Revista dos Tribunais, 2014.

GOBRI, I. Vocabulário grego da filosofia. São Paulo: Martins Fontes, 2007.

HABERMAS, J. Consciência moral e agir comunicativo. Rio de Janeiro: Tempo Brasileiro, 1989.

HABERMAS, J. Direito e Democracia: entre facticidade e validade. 4. ed. Trad. Flávio Beno Siebeneichler. Rio de Janeiro: Tempo Brasileiro, 1997. 
HEGEL, G. W. F. A Razão na História: Uma introdução geral à Filosofia da História. Trad. Beatriz Sidou. 2. ed. São Paulo: Centauro, 2001.

HEGEL, G. W. F. Introdução à história da filosofia. Trad. Antônio Pinto de Carvalho. São Paulo: Abril Cultural, 1980.

HEGEL, G. W. F. Princípios da filosofia do direito. Trad. Orlando Vitorino. 1. ed. São Paulo: Martins Fontes, 1997.

INWOOD, M. Dicionário Hegel. Trad. Álvaro Cabral. Rio de Janeiro: Zahar, 1997.

JAIME, B. P.; AMADEO, J. O conceito de liberdade nas teorias políticas de Kant, Hegel e Marx. In: BORON, A. (Org.). Filosofia política moderna. De Hobbes a Marx. São Paulo: USP, 2006, p. 405-424.

JAPIASSÚ, H.; MARCONDES, D. Dicionário básico de filosofia. Rio de Janeiro: Zahar, 2006.

JASPERS, K. Introdução ao pensamento filosófico. 3. ed. São Paulo: Cultrix, 1965.

LACOSTE, J. Filosofia da arte. 2 ed. Rio de Janeiro: Zahar, 1986.

LARA, T. A. A filosofia nas suas origens gregas. 4. ed. Petrópolis: Vozes, 1989.

MERLEAU-PONTY, M. Fenomenologia da percepção. 3. ed. São Paulo: Martins Fontes, 1999.

MODIM, B. O homem: quem é ele? Elementos de antropologia filosófica. 6. ed. São Paulo: Paulinas, 2005.

MORA, J. F. Dicionário de filosofia. 4. ed. São Paulo: Martins Fontes, 2001.

PIRES, F. P. Liberdade e religião no existencialismo de Jean-Paul Sartre. Sacrilegens, v. 2, n. 1, p. 2-21, 2005.

PLATÃO. A República. Trad. Pietro Nassetti. São Paulo: Martin Claret, 2002.

REALE, G.; ANTISERI, D. História da filosofia 1: filosofia pagã antiga. Trad. Ivo Storniolo. São Paulo: Paulus, 2003.

REALE, G.; ANTISERI, D. História da filosofia 5: do romantismo ao empiriocriticismo. Trad. Ivo Storniolo. São Paulo: Paulus, 2005.

REALE, G. História da Filosofia Antiga. Trad. Henrique Cláudio de Lima Vaz e Marcelo Perine. São Paulo: Loyola, 1994.

RODRIGUES, O. M.; GONDIM, E. Descartes e Sartre: a questão da liberdade. Ensaios Filosóficos, v. VI, p. 113-128, 2012.

SALGADO, J. C. A Idéia de Justiça em Hegel. São Paulo: Loyola, 1996.

SARTRE, J. P. O ser e o nada: ensaio de ontologia fenomenológica. 24. ed. Trad. Paulo Perdigão. Petrópolis: Vozes, 2015.

SCHNEIDER, D. R. Liberdade e dinâmica psicológica em Sartre. Natureza Humana, v. 8. n. 2, p. 283-314, 2006.

SILVA, A. M. V. B. A concepção de liberdade em Sartre. Filogenese, v. 6, n. 1, p. 93-107, 2013.

SILVA, P. C. G. O conceito de liberdade em O ser e o nada de Jean-Paul Sartre. 2010. $110 \mathrm{f}$. Dissertação (Mestrado em Filosofia) - Centro de Ciências Humanas, Letras e Artes, Universidade Federal do Rio Grande do Norte, Natal, 2010.

VALLS, A. L. M. O que é ética. São Paulo: Brasiliense, 2005.

WEBER, T. Direito, justiça e liberdade em Hegel. Textos \& Contextos, v. 13, n. 1, p. 20-30, 2014. 